\title{
COMPARISON OF INDUSTRIAL AND CLASSROOM MANAGEMENT SYSTEMS USING THE MODEL OF CYBERNETIC OF THIRD ORDER
}

\author{
ORLANDO GARCÍA H, ROBERTO M. POVEDA C \& MIGUEL A. ÁVILA A
}

Engineering, Faculty, Universidad Distrital Francisco José de Caldas, Bogotá, Colombia

\begin{abstract}
This article features an investigation that compares the industrial management systems and the management systems of class in the classroom who supplies a base of education system management using the available beginnings in the industrial management systems. For that is presented a method aims to:

- Identify the comparability of the industrial management systems with the classroom management systems using the framework of cybernetics of third-order proposed on (Nova Arévalo\&Pinzón Rueda, 2013).

- Identify the effect of the practices in the classroom in the learning of signatures of the field of mathematical modeling, in students of engineering of universities of Colombia, using the reply theory to item.

The investigation starts with the problem approach where it assumes the unique paper or value of engineering is to be a "calculation machine" to "solve problems" to thirds, who in general are who subsidize.

KEYWORDS: Industrial Management Systems \& Cybernetics in Third-Order
\end{abstract}

Received: Jun 08, 2020; Accepted: Jun 28, 2020; Published: Sep 15, 2020; Paper Id.: IJMPERDJUN20201252

\section{INTRODUCTION}

This investigation identifies the grade of extrapolation of the organizing beginnings of the industrial management systems to the classroom management systems, so, it is located in the ambit of the education and extrapolation of the beginnings of the industrial management to the education management.

To achieve the extrapolation first, take the framework of the cybernetics of third order, then with that identify the components of three industrial management systems widely spread and the theory of classroom management systems. Later, compare the efficiency of the classroom management systems used in the formation in mathematics in engineering in universities of Bogotá. Then identify the assumption of the impossibility of the comparison about the classroom management systems, given this, some similar approaches to the previous are made about the study of the educative systems and its assumed that these when treating with people, the beginnings and the improvement techniques of industrial management systems cannot be used as the more efficient management of this type of organization for being social.

However, despite these identified obstacles and impediments like assumptions of some approaches, implies disclaim the fundamentals of the intervention or the use of the engineering techniques to the previous education management like:

- The use of engineering to design the best facilities and information and education procedures, well be in methods and physical facilities as it does the competency engineering (Le Boterf, 2001). 
- The use of engineering to identify the best framework of practices to the engineering formation, as recommended of the experience of more than 50 years of formation in engineering mentioned in (Heywood,2005).

- The use of evolution in a discipline of the control systems, discipline known as dynamic systems for the management of educational systems and the organizational learning processes (Senge, 2000).

- The use of concepts of economic engineering to assess and manage economically the educative process from the economics of education (Villa A., 2001).

In the economy is used the own registers of the educative activity and is compare direct and explicit with the productive systems through the functions of production and costing and the respective dual functions, in the mathematical optimization language and linear programs, where the data used could be measures of academic performance of the students, is evaluating the educative system or parts of these with evaluation criteria of an industrial productive economic system.

For the above mentioned are multiple studies who treat to identify the functions of production in education since 1950 , that is to say identify the education as a production system. Some approaches used are:

- Statistical techniques based in linear models (Smart, 2009).

- In linear programming models, as the approach DEA (Cooper, 2007).

- On stochastic production surfaces (Kumbhakar, 2000).

- In structural equations (Hancock \&Muelle, 2006).

However, these techniques don't compare the educational systems with the industrial management systems from the point of view of engineering and this process, the comparison is made of inputs against results without detailing the effects of the selection management method. This is because the economy doesn't study the management system, this studies the results and the inputs of the system.

The comparison proposed here is made using the cybernetic theory of third order, with this frame is studied the classroom systems and the industrial management systems.

\section{APPLIED METHODOLOGY}

The investigation methodology was developed below a qualitative approach and the theoretical bases of the investigationaction, whose fundamental purpose focusing on improving the quality of an action, in this case of the education through theory and practice advantages.

This was carried out under the following work system:

- Bibliographic synthesis of Cybernetics of the third-order, classroom management systems, engineering formation models, engineering of competencies, the economy of the education, industrial management systems.

- Definition of parameters of comparison of the industrial management systems

- Selection of industrial management systems to compare.

- Comparison of industrial management systems and the identification of common systems, eighth element. 
- Association of common elements in the industrial management systems with the elements of the cybernetic model of third-order, eighth element.

- Definition of measurement parameters of the classroom management systems.

- Elaboration and application of ZTPI and initial knowledge test to the students object of study.

- Association of the factors of the classroom management systems with the cybernetic model in third-order of the industrial management systems.

- Elaboration and application of intermediate and knowledgetests and at the end of the process (semester).

- Formulation of the cybernetic model of third-order for the classroom management systems.

- Proposal of extension framework of the beginnings of industrial management systems to the beginning of classroom management systems.

\subsection{Structure of the Investigation}

A method was available to compare different fields of knowledge, as they are:

- Industrial management system.

- Classroom management system.

\subsection{1}

- $\quad$ System and observer.

- Model.

- Cybernetics like science.

- Cybernetic and its scope.

- Cybernetic of the first, second, and third-order.

- Elements of Cybernetic of the third-order.

\subsection{2}

- Industrial.

- Production.

- To define industrial engineering.

- Define engineering of production.

- Distinguish between Industrial engineering and engineering of production.

2.1.3.

- $\quad$ Management.

- Industrial. 
- Production.

- Management and Production System.

- Industrial production of the management system.

2.1.4.

- Classroom.

- Education.

- Education in the classroom.

- Classroom management system.

- Educative systems and classroom systems.

2.1.5.

- Industrial management.

- Management of production.

- Production.

- $\quad$ Education models.

- Models.

- Models of productive systems.

- The framework to compare pedagogic devices.

- Techniques to compare systems, disciplines, methodologies, and models.

2.1.6.

- $\quad$ Strategic.

- Organizational.

- $\quad$ Tactic.

- Operational.

2.1.7.

- Scholarship, the education system.

- Pedagogy.

2.1.8.

- Toyota.

- ERP 
- TOC.

2.1.9.

- Personalized education.

- Accompaniment.

- Classroom.

- Master class.

\subsubsection{0}

- Industrial management system.

- Classroom management system.

However, the obtained result of the comparison of saying systems just is a general framework of identification of the components of the systems since the perspective of the cybernetics of third order in terms of his:

\subsection{1}

- Correspondence.

- Articulation.

- Conceptualization.

The comparison of the education management systems with the classroom management systems is out of the scope of this text. However, based on the comparison of the production management systems, the systems in the ninth and tenth steps are compared, this constitutes the eleventh step. This comparison has been made in terms of the concepts and components of the two types of systems.

\subsubsection{2}

- The frame to compare the pedagogical devices.

- The identification theories of the people characteristics: Item response theory and time perspective of Zimbardo.

- The design of the knowledge tests.

- The characterization of the population.

\subsubsection{3}

Identification of the respective sample frame and the process of record taking, as well as the characterization of the classroom management system.

\subsubsection{4}

A distinction of the effect of the characteristics of the classroom management system in the subject training, this is distinguished from the characteristics of the individual captured in: 
- $\quad$ Item response theory

- $\quad$ Time perspective of Zimbardo

\section{RESULTS}

In this investigation is used the ZTPI (Time perspective Inventory - ZTPI (Zimbardo \& Boyd, 2008) which explains close to $80 \%$ of the decision-making the process of a person through your perception of time, to determine the decision profile of the engineering students that shape the object of study) for this is applied a standard test at the start of the investigation and in the final of these, in this way was determined if the classroom systems used for the learning in mathematics affect the decision-making model of the students. A total of 576 complete registers, corresponding to an equal number of students, were taken into account in this investigation, corresponding to 6 subjects taught: Probability, Statistics, Linear algebra, Numerical analysis, Operations research and Design of experiments in fourth institutions of higher education: Universidad Distrital, Piloto, CUN and EAN. The academic programs are: Business administration, Economy, International business and Civil, Environmental, Financial, Industrial, Mechatronic Production, Systems and Telecommunications engineering.

The initial amount of people identified for each test is in the table 1 . There they register 576 students potentials to being evaluated in the next structure of test:

- Time inventory of Zimbardo of input.

- Input diagnostic test.

- Evolution test 1.

- $\quad$ Evolution test 2 .

- $\quad$ Diagnostic test 2.

- Time inventory of Zimbardo of output.

The final number of people presented by each of the tests It's in table 2. There it is identified that of the 470 people who present some test, from Zambardo's time perspective inventory, which:

- 385 people presented the initial test.

- 370 presented the final test. 
Table 1: Composition of Study Participants

\begin{tabular}{|c|c|c|c|c|c|c|c|c|}
\hline PLANTA & Carrera & ASIGNATURA & Área & $\begin{array}{c}\text { No } \\
\text { estudiantes } \\
\text { en lista }\end{array}$ & \begin{tabular}{|c|} 
No \\
estudiantes \\
que \\
presentaron \\
\end{tabular} & $\begin{array}{c}\text { horas } \\
\text { totales en } \\
\text { el aula }\end{array}$ & $\begin{array}{c}\text { Horas } \\
\text { netas } \\
\text { trabajadas }\end{array}$ & $\begin{array}{l}\text { Horas de } \\
\text { tutoría }\end{array}$ \\
\hline \multirow{3}{*}{$\begin{array}{c}\text { Escuela } \\
\text { Superior de } \\
\text { Cadetes }\end{array}$} & Administración & Estadistica & Estadistica & 41 & 41 & 40 & 32 & 8 \\
\hline & Administración & Estadistica & Estadistica & 39 & 37 & 40 & 32 & 8 \\
\hline & Administraciön & Investigación de operaciones & Optimización & 44 & 44 & 72 & 40 & 32 \\
\hline \multirow{3}{*}{$\begin{array}{c}\text { Corporación } \\
\text { Unificada } \\
\text { Nacional }\end{array}$} & Ingenieria & Investigación de operaciones & Optimización & 51 & 51 & 48 & 48 & 0 \\
\hline & Ingenieria & Análisis numérico & Optimización & 31 & 31 & 48 & 48 & 0 \\
\hline & Inpenieria & Análisis Numérico & Optimización & 29 & 29 & 48 & 48 & 0 \\
\hline \multirow[t]{4}{*}{ Universidad } & \begin{tabular}{|l|} 
Ing civil \\
\end{tabular} & Probablliad & Probabilidad & 30 & 26 & 64 & 55 & 0 \\
\hline & Ing Mecatronica & Agebra Lineal & Optimización & 38 & 30 & 64 & 60 & 0 \\
\hline & Ing Mecatronica & Estadistica & Estadistica & 36 & 31 & 64 & 58 & 0 \\
\hline & Ing Mecatronica & Estadistica & Estadistica & 44 & 43 & 64 & 60 & 0 \\
\hline Piloto & Administración & Estadística & Estadistica & $M$ & $M$ & 64 & 60 & 0 \\
\hline \multirow[t]{2}{*}{ Universidad } & Ing. Producción & Modelos deterministicos & Optimización & 45 & 17 & 64 & 46 & 0 \\
\hline & Ing. Producción & Disefio de Experimentos & Estadistica & 32 & 18 & 64 & 36 & 0 \\
\hline Distrital & Ing. Producción & Modelos Estocásticos & Probabilidad & 42 & 28 & 64 & 42 & 0 \\
\hline \multicolumn{3}{|c|}{ Total } & & 546 & 470 & & & \\
\hline
\end{tabular}

\section{Source: Authors.}

Table 2 shows that of the 470 people who register the tests, 249 have qualifications in the two time inventories of Zimbardo and the two diagnoses; 165 have complete records for all six tests. And the evidence of interest shows that there are 193 records. This can happen because:

- $\quad$ Not all people attend all tests

- $\quad$ Some evidence presented is not fully answered

Comparing the results of tests 1 and 6, we observe the change in the ZTPI profile in the 5 aspects of Zimbardo's time inventory to identify the variation of the subject's time perspective.

Comparing the results of the diagnostic tests of entry and exit, we observe the advance in global tests of knowledge in each of the aspects of these. 
Table 2: Breakdown of Participants in the Study

\begin{tabular}{|c|c|c|c|c|c|c|c|c|c|c|}
\hline Planta & ASIGNATURA & Tiknen & Tienen & $\begin{array}{c}\text { Tienen } \\
\text { Diagnóstico } \\
\text { Inićal } \\
\end{array}$ & $\begin{array}{c}\text { Tienen } \\
\text { Diagnóstico } \\
\text { Final } \\
\end{array}$ & $\begin{array}{l}\text { Tenen } \\
\text { Pruebâ } \\
\text { evolución1 }\end{array}$ & $\begin{array}{l}\text { Tienen } \\
\text { Pruebo } \\
\text { evolución } 2 \\
\end{array}$ & $\begin{array}{l}\text { Tiene Todas } \\
\text { las ZTPIy } \\
\text { Diagnósticos }\end{array}$ & $\begin{array}{c}\text { Con ZTPI1Y } 2 \\
\text { y pruebas } 1 \text { y } \\
2\end{array}$ & apruebas \\
\hline \multirow[t]{2}{*}{ ECSAN } & Estadistica & 65 & 48 & 32 & 52 & 0 & 0 & 19 & 0 & 0 \\
\hline & Investigadónde Operaciones & 33 & 30 & 20 & 31 & 0 & 0 & 12 & 0 & 0 \\
\hline \multirow[t]{2}{*}{ CUN } & Análisis Numério & QD & 60 & 59 & Q & 60 & 59 & 59 & 59 & 58 \\
\hline & Irrestigatónde Operaciones & 50 & 50 & 50 & 50 & 50 & 49 & 50 & 49 & 49 \\
\hline \multirow[t]{3}{*}{ PILTO } & Álgebra Lineal & 22 & 22 & 30 & 14 & 26 & 27 & 6 & 14 & 6 \\
\hline & Estadsictica & 90 & 82 & 100 & $\pi$ & 87 & 95 & 50 & 57 & M \\
\hline & Probabilad & 20 & 15 & 15 & 13 & 20 & 17 & 9 & 14 & 8 \\
\hline \multirow[t]{3}{*}{$=U D$} & Disefo Experimerto & 28 & 28 & 27 & 28 & 28 & 0 & 27 & 0 & 0 \\
\hline & Ciodelos deterministicos & 17 & 17 & 17 & 17 & 17 & 0 & 17 & 0 & 0 \\
\hline & Thodalos Estocástioos & 0 & 18 & 0 & 17 & 18 & 0 & 0 & 0 & 0 \\
\hline Total general & & 365 & 370 & 350 & 359 & 306 & 297 & 249 & 193 & 165 \\
\hline
\end{tabular}

\section{Source: authors}

The following table indicates that the amount of information explained by these factors is $17 \%$, identified in the coefficient of determination. From there it can be observed that the configuration of the systems with the inclusion of these elements identify that if the concepts are homologized, that is to say, it is observed that with the identified factors one can speak of an impact or utility of the concepts of industrial management of $16 \%$ in the systems of classroom management, quantify that has not yet been determined in any of the referents identified in the bibliographical review.

Table 3: Degree of Approximation of Industrial Management System Concepts with Classroom Management Systems.

\begin{tabular}{|r|r|r|r|r|r|r|r|}
\hline Variate & Canonical & & & Num & Den & \multicolumn{1}{l|}{ Prob } & Willks' $^{\prime}$ \\
\hline Number & Correlation & R-Squared & F-Value & DF & DF & Level & Lambda \\
\hline 1 & 0,406 & 0,165 & 1,980 & 21 & 526 & 0,0061 & 0,8038 \\
\hline 2 & 0,161 & 0,026 & 0,590 & 12 & 368 & 0,3513 & 0,9627 \\
\hline
\end{tabular}

Source: authors.

\section{CONCLUSIONS AND RECOMMENDATIONS}

4. 1. Some concepts of classroom management systems are comparable to industrial management systems

4. 2. Industrial engineering concepts can be extrapolated to the management of classroom systems and educational systems

4.3. Progress in learning is associated with how the classroom is managed

4. 4. The factors that affect classroom performance, in terms of statistical significance are:

- An institutional component.

- The effect of the teacher.

- The size of the group. 
- $\quad$ The number of contact hours of work.

- The specific study group.

- No effect on students' time perspective.

- The students time perspective wasn't modified

4.5. The beginnings of industrial engineering could affect in $17 \%$ the management of classroom management systems, according to the canonical relation who compares the classroom management systems and the industrial management systems in the unbiased scores of learning of the subjects made with TRI. The input is visible since it commonly doesn't appear in the line of the TSI.

For the above, the recommendations for future studies are as follows:

- More factors identified in the management of industrial systems can be expanded to obtain the size of the usable effect of the principles or methods of management of industrial production systems.

- More resources could be operationalized to identify the cognitive style of the subject and its effect on progress.

- It is suggested to maintain the scheme of obtaining data without reward mediation since the rewards and their perception affects the performance or orientation of the tests, affecting the scores

- Measure or compare with more institutions, programs, and cycles over the 16-week semester. Industrial management systems in the unbiased scores of learning of the subjects made with TRI. The input is visible since it commonly doesn't appear in the line of the TSI.

\section{REFERENCES}

1. Cooper, W. W. (2007). A comprehensive text with models, applications, references and DEA-solver software. New York: Springer.

2. Hancock, G. R., \& Muelle, R. O. (2006). Structural equation modeling: a second course. Greenwich: IAP.

3. Heywood, J. (2005). Engineering education : research and development in curriculum and instruction. Hoboken, N.J: IEEE Press.

4. Kumbhakar, S. (2000). Stochastic frontier analysis. New York: Cambridge University Press

5. Le Boterf, G. (2001). Ingeniería de las Competencias. Gestión 2000.

6. Nova Arévalo, N. A., Pinzón Rueda, W. A. (2013). Hacia un nuevo modelo de cibernética, una aproximación al tercer orden (Espacios ed.). Bogotá, Colombia: Universidad Distrital Francisco José de Caldas.

7. Smart, J. C. (2009). Handbook of theory and research. London : Springer.

8. Senge, P. (2000). Schools that learn: a fifth discipline fieldbook for educators, parents, and everyone who cares about education. New York: Doubleday

9. Suarez, C. (2014). Comparación de sistemas de gestión industrial y de aula usando el modelo de cibernética de tercer orden. [Thesis] Magister enIngeniería Industrial.

10. Villa A., C. L. (2001). Economía de la educación, con énfasis en educación superior: notas de clase .Bogotá: Universidad de los Andes. 

